\title{
PENERAPAN PENDEKATAN CREATIVE PROBLEM SOLVING TERHADAP PENINGKATAN KEMAMPUAN PEMECAHAN MASALAH MATEMATIK SISWA KELAS XII RPL B SMK NEGERI 1 CIMAHI
}

\section{Fauziah}

\author{
Sekolah Menengah Kejuruan Negeri 1 Cimahi \\ fauziah.dra@gmail.com
}

\begin{abstract}
ABSTRAK
Penelitian ini adalah penelitian tindakan kelas. Masalah yang dirumuskan dalam penelitian ini adalah dengan mengetahui apakah adanya peningkatan kemampuan pemecahan masalah matematika siswa SMK dengan pendekatan Creative Problem Solving. Penelitian ini dilaksanakan pada siswa Kelas XII RPL B SMK Negeri 1 Cimahi tahun pelajaran 2016/2017 dengan jumlah siswa 36 orang. Instrument yang digunakan adalah tes hasil belajar sebagai tes kemampuan pemecahan masalah matematik siswa, untuk tes awal (sebelum tindakan), tes siklus I dan tes siklus II (setelah pemberian tindakan), dan lembar observasi bagi guru dan bagi siswa untuk kondisi pelaksanaan tindakan. Prosedur penelitian ini terdiri dari: (1) perencanaan, (2) pelaksanaan tindakan, (3) observasi dan evaluasi dan (4) refleksi. Berdasarkan hasil penelitian tindakan kelas yang telah dilakukan, pada pelajaran trigonometri siswa kelas XII RPL B SMK Negeri 1 Cimahi, bahwa pembelajaran trigonometri dengan pendekatan pembelajaran Creative Problem Solving dapat meningkatkan kemampuan pemecahan masalah matematik siswa. Hal ini dapat terlihat dari hasi ltes kemampuan pemecahan masalah matematik siswa yang mengalami peningkatan. Hasil tes kemampuan pemecahan masalah matematik pada tes awal hanya memiliki rata - rata kelas 65, 22. Padasiklus I, hasil tes meningkat cukup signifikan menjadi 71, 81. Pada siklus II mengalami perbaikan lagi dan ratarata kelas untuk nilai tes kemampuan pemecahan masalah matematik siswa mencapai 83,08
\end{abstract}

Kata Kunci : Creative Problem Solving, Siswa, SMK

\begin{abstract}
This research is a classroom action research. The problem formulated in this research is to find out whether there is an improvement in the problem solving skills of SMK students with the approach of Creative Problem Solving. This research was conducted on the students of Class XII RPL B SMK Negeri 1 Cimahi tahun 2016/2017 with the number of students 36 people. The instrument used is a test of learning outcomes as a test of students' mathematical problem solving skills, for preliminary (before action) tests, cycle I and cycle II tests (after giving of action), and observation sheets for teachers and for students for the conditions of action implementation. The procedures of this study consist of: (1) planning, (2) implementation of action, (3) observation and evaluation and (4) reflection. Based on the results of classroom action research that has been done, in trigonometry lesson class XII RPL B SMK Negeri 1 Cimahi, that trigonometric learning with Creative Problem Solving learning approach can improve students problem solving abilities of mathematics. This can be seen from the mathematical problem solving ability of students who have improved. Mathematical problem solving test results in the initial test only have a grade average of 65, 22. In the first cycle, the test results increased significantly to 71, 81. In the second cycle again improved and the average class for the test value of mathematical problem solving skills students reached 83,08
\end{abstract}

Keyword: Creative problem solving 
PENDAHULUAN

Menurut National Council of

Teachers of Mathematics (NCTM)

(Sroyer, 2013:25), tujuan pembelajaran matematika adalah mengembangkan kemampuan: komunikasi matematik, penalaran matematik, problem solving matematik, koneksi matematik, dan representasi matematik. Lebih lanjut menurut NCTM, salah satu keterampilan matematika yang perlu dikuasai siswa adalah kemampuan problem solving matematik. Standar problem solving, National Council of Teachers of Mathematics (NCTM) menetapkan bahwa program pembelajaran dari pra-taman kanak-kanak sampai kelas 12 harus memungkinkan siswa untuk: membangun pengetahuan matematika baru melalui problem solving; memecahkan masalah yang muncul di dalam matematika dan di dalam konteks-konteks yang lain; menerapkan dan menyesuaikan bermacammacam strategi yang sesuai untuk memecahkan masalah; dan memonitor dan merefleksikan proses dari problem solving matematika

Polya (dalam Hamiyah \& Jauhar, 2014:120) mengartikan pemecahan masalah sebagai suatu usaha mencari jalan keluar dari satu kesulitan guna mencapai satu tujuan yang tidak begitu mudah segera untuk dicapai. Sedangkan Jacobsen, Eggen, \& Kauchak (2009, p. 249) mendefinisikan pendekatan problem solving sebagai salah suatu pendekatan yang menuntut guru untuk membantu siswa dalam belajar memecahkan masalah melalui pengalaman pembelajaran handson. Pengalaman pembelajaran hands-on artinya siswa berinteraksi langsung dengan masalah yang diberikan guru. Berinteraksi dimulai dari ketika masalah dihadapkan kepada siswa sampai pada ketika solusi terbaik telah dimiliki siswa. Interaksi siswa dengan masalah ini pun diharapkan mampu membantu siswa dalam menemukan konsep matematika tertentu yang terkandung dalam pemecahan masalah. Melalui pembelajaran ini siswa belajar memecahkan masalah untuk mendapatkan pemahaman sendiri, sehingga siswa belajar melalui pengalamannya. Pengalaman belajar dengan pendekatan problem solving membantu siswa mengembangkan kemampuan berpikir kritisnya. Adapun langkah-langkah pembelajaran dengan menggunakan pendekatan ini adalah orientasi masalah, pemecahan masalah, presentasi kelas, dan penyelesaian latihan soal (Van de Walle, 2008, pp. 43-49). Kemampuan pemecahan masalah amatlah penting dalam matematika, bukan saja bagi mereka yang di kemudian hari akan mendalami atau mempelajari matematika, melainkan juga bagi mereka yang akan menerapkannya dalam bidang studi lain dan dalam kehidupan sehari-hari (Sroyer, 2013:25)

Kemampuan pemecahan masalah merupakan salah satu kemampuan penting yang harus dimiliki oleh semua siswa. Namun kenyataannya, kemampuan pemecahan masalah Matematika siswa Indonesia sangat memprihatinkan. Hal ini bisa diamati berdasarkan hasil studi TIMMS tahun 2011 (Trends in International Mathematics and Science Study) yang menunjukkan bahwa siswa Indonesia berada pada ranking amat rendah yaitu berada pada peringkat ke-38 dari 45 negara yang berpartisipasi pada penilaian tersebut. Siswa indonesia mengalami kesulitan dalam kemampuan (1) memahami informasi yang komplek, (2) teori, analisis dan pemecahan masalah, (3) pemakaian alat, prosedur dan pemecahan masalah dan (4)melakukan investigasi (Pratiwi, 2013:42).

Faktor penyebab kesulitan siswa dalam menyelesaikan soal pemecahan masalah matematik adalah pemahaman siswa pada soal pemecahan masalah masih rendah, siswa belum mampu menganalisa maksud dan tujuan soal, siswa belum mampu memilih dan mengaplikasikan rumus yang sudah diperoleh selain itu kurangnya latihan dalam menyelesaikan soal pemecahan masalah matematik, 
sehingga siswa mudah menyerah ketika diberikan masalah-masalah yang harus dipecahkan. Penggunaan metode yang kurang bervariatif juga sangat berpengaruh pada proses belajar-mengajar khususnya kemampuan pemecahan masalah matematik. Oleh karena itu, penulis menyimpulkan untuk meningkatkan kemampuan pemecahan masalah matematik siswa salah satunya dengan pendekatan Creative Problem Solving, karena pada pembelajaran yang menggunakan pendekatan Creative Problem Solving terdapat beberapa langkah yang akan membantu siswa dalam memecahkan suatu masalah.

$$
\text { Karen (Sari, 2013:27) }
$$

menyebutkan bahwa "Creative Problem Solving adalah suatu pendekatan pembelajaran yang berpusat pada keterampilan pemecahan masalah yang diikuti dengan penguatan kreativitas". Isaksen dalam Hafitria pada tahun 2015 menguraikan proses pembelajaran Creative Problem Solving dalam tiga langkah utama yaitu memahami masalah, membangkitkan ide dan merencanakan tindakan. Dalam memahami masalah meliputi tahapan menemukan tujuan, menemukan data atau fakta-fakta dan menemukan masalah sebagai target pertanyaan. Dalam membangkitkan ide mencakup penurunan pilihan-pilihan untuk menjawab masalah terbuka (open-ended). Sedang dalam merencanakan tindakan meliputi tahap menemukan solusi dan menemukan dukungan (acceptancefinding).

Menurut Sanjaya (Suhendar, 2014:11), kelebihan pendekatan Creative Problem Solving adalah:

a. Merupakan teknik yang cukup bagus untuk memahami isi pelajaran.

b. Dapat menantang kemampuan siswa serta memberikan kepuasan untuk menemukan.

c. Dapat meningkatkan aktivitas pembelajaran siswa.

d. Dapat membantu siswa bagaimana mentransfer pengetahuan mereka untuk memahami masalah dalam kehidupan nyata.

e. Dapat membantu siswa dalam mengembangkan kemampuan barunya dan bertanggung jawab dalam pembelajaran yang mereka lakukan.

f. Dapat mendorong evaluasi sendiri baik terhadap hasil maupun proses belajarnya

Berdasarkan uraian permasalahan dan pendapat-pendapat para ahli di atas, maka peneliti tertarik untuk mengadakan penelitian tindakan kelas dengan judul "Penerapan Pendekatan Creative Problem Solving terhadap Peningkatan Kemampuan Pemecahan Masalah Matematik Siswa Kelas XII RPL B SMK Negeri 1 Cimahi”

\section{METODE}

Penelitian ini dilaksanakan pada semester genap tahun akademik 2016/2017 di SMK Negeri 1 Cimahi Kota Cimahi dengan subjek penelitian adalah siswasiswi kelas XII RPL B dengan jumlah siswa 36 orang terdiri dari 19 orang lakilaki dan 17 orang perempuan. Penelitian tindakan kelas ini dilakukan secara bertahap. Adapun tahap pelaksanaan penelitian sebagai berikut :

\section{Perencanaan}

Tahap perencanaan ini meliputi penyusunan RPP, membuat lembar observasi dan mendesain alat evaluasi.

\section{Pelaksanaan}

Pada tahap ini, kegiatan dilaksanakan sesuai dengan rencana pembelajaran yang telah dibuat. Dalam pelaksanaan penelitian, setiap siklus terdiri dari 2 (dua) kali pertemuan.

\section{Observasi dan evaluasi}

Pada tahap ini peneliti mengamati siswa pada saat proses pembelajaran berlangsung. Mulai dari saat peneliti menerangkan materi, mengajukan permasalahan, pada saat siswa melakukan diskusi kelompok dan penyampaian penyelesaian masalah dari masing-masing kelompok. Pada saat pengamatan ini peneliti dibantu oleh observer. 


\section{Refleksi}

Tahap keempat adalah refleksi yaitu kegiatan untuk mengemukakan kembali apa yang telah dilakukan selama proses pembelajaran. Pengamat dan peneliti yang juga berperan sebagai pengamat mendiskusikan implementasi rancangan tindakan. Pada tahap ini dilakukan juga analisis data yang telah diperoleh. Hasil analisis data yang telah ada dipergunakan untuk melakukan evaluasi terhadap proses yang telah dilakukan pada siklus sebelumnya dan hasil yang ingin dicapai serta secara cermat mengenali hal-hal yang masih perlu diperbaiki pada siklus berikutnya

\section{Data Dan Teknik Pengambilan Data}

1. Sumber data yaitu personil penelitian yang terdiri dari guru dan siswa.

2. Jenis data yaitu data kuantitatif dan kualitatif yang diperoleh dari lembar observasi, dan tes hasil belajar.

3. Cara pengumpulan data:

a. Data mengenai pelaksanaan pembelajaran diambil dengan menggunakan lembar observasi terhadap guru dan siswa.

b. Data mengenai kemampuan pemecahan masalah matematik diambil dengan menggunakan tes meliputi tes awal, tes siklus I dan tes siklus II

\section{HASIL DAN PEMBAHASAN Kegiatan Pendahuluan}

Dalam pembelajaran matematika mengenai materi trigonometri ini, pendekatan yang digunakan adalah pendekatan creative problem solving dalam rangka mengatasi permasalahan yang dihadapi. Penelitian tindakan kelas ini dilakukan dalam 2 siklus yang terdiri dari 2 pertemuan tiap siklusnya.

Sebelum memasuki tahap pemberian tindakan, siswa diberikan tes awal untuk melihat kemampuan pemecahan masalah matematik siswa mengenai materi trigonometri. Guru dan peneliti memberikan tes awal secara tertulis. Pelaksanaan tes menggunakan 2 jam pelajaran dan berlangsung dengan lancar dan terkendali. Pemberian tes awal ini sebagai acuan seberapa besar peningkatan kemampuan pemecahan masalah matematik siswa selama pendekatan creative problem solving diterapkan. Dari nilai tes awal yang diperoleh menunjukkan bahwa nilai ratarata kemampuan pemecahan masalah matematik siswa masih rendah, yaitu 65,22dari nilai maksimal yang mungkin dicapai siswa yaitu 100 .

\section{Tindakan Siklus I dan Siklus II}

Hal-hal yang dilakukan pada tahap ini adalah pembuatan rencana pelaksanaan pembelajaran (RPP) berdasarkan silabus yang dijadikan acuan penelitian. RPP yang dibuat untuk siklus I terdiri dari 2 pertemuan pada materi "Trigonometri". Penerapan pendekatan Creative Problem Solving siklus I dilakukan dengan ceramah, tanya jawab, diskusi dan penugasan.

Kemudian peneliti membuat lembar observasi untuk guru dan siswa, dimana aspek yang diobservasi menurut langkah-langkah pembelajaran pada RPP, dan merancang perangkat evaluasi untuk tes siklus I. Tindakan siklus I dilaksanakan dalam dua kali pertemuan. Setelah 2 kali pertemuan dan pada pertemuan kedua diadakan tes siklus I, didapatkan hasil tes siswa dengan nilai rata-rata lebih tinggi dari tes awal. Nilai rata-rata siswa tersebut yaitu 71,81 . Kemudian pada pertemuan selanjutnya dilakukan pembelajaran siklus II sebanyak 2 pertemuan. Dari hasil pembelajaran dan tes pada siklus II, didapatkan hasil tes siswa dengan nilai rata-rata lebih tinggi dari tes awal dan tes siklus I. Nilai rata-rata siswa tersebut yaitu 83,08 .

Dengan demikian, siswa dapat mengerjakan soal cerita trigonometri semakin bertambah dibandingkan tes awal. Dengan kata lain, hasil tes siklus I dan II menunjukkan bahwa kemampuan pemecahan masalah siswa mengalami peningkatan bila dibandingkan tes awal. Di samping itu, rata-rata nilai tes siklus I 
yang diperoleh yaitu 71,81 dan rata-rata nilai tes siklus II yang diperoleh yaitu 83, 08. Hal ini menunjukkan bahwa nilai ratarata kemampuan pemecahan masalah siswa sudah meningkat bila dibandingkan dengan rata-rata hasil tes awal seperti grafik berikut:

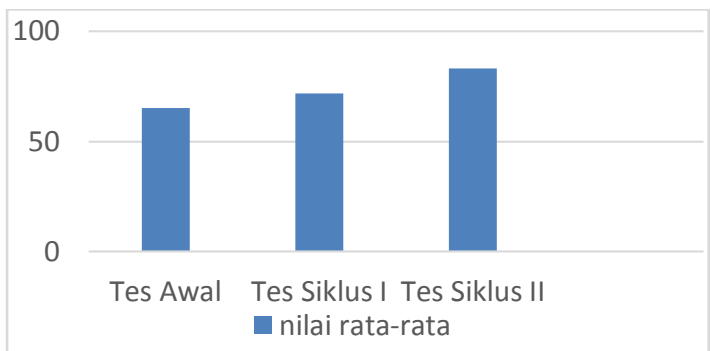

Hasil penelitian ini sejalan dengan penelitian yang sebelumnya, dilakukan oleh Mariyam (2011) di SD Negeri Ujung Berung 3 menyimpulkan bahwa pembelajaran matematika dengan menggunakanModel Pembelajaran Matematika creative problem solving dapat meningkatkan hasil pembelajaran siswa kelas VI SDN Ujung Berung 3 pada pokok bahasan volum bangun ruang. Dari hasil penelitian Hafitria (2015) di SMP 12 Bandung dapat disimpulkan bahwa pembelajaran matematika dengan menggunakanModel Pembelajaran Matematika Creative Problem solving dapat meningkatkankemampuan pemecahan masalah matematis dan berpikir kreatifmatematis siswa SMP. Dengan demikian, pendekatan Pendekatan Creative Problem Solving dapat dijadikan salah satu alternative untuk meningkatkan kemampuan pemecahan masalah matematik siswa SMK

\section{SIMPULAN}

Berdasarkan hasil penelitian tindakan kelas yang telah dilakukan, pada pelajaran trigonometri siswa kelas XII RPL B SMK Negeri 1 Cimahi diberikan kesimpulan, bahwa pembelajaran trigonometri dengan pendekatan pembelajaran Creative Problem Solving dapat meningkatkan kemampuan pemecahan masalah matematik siswa. Hal ini dapat terlihat dari hasil tes kemampuan pemecahan masalah matematik siswa yang mengalami peningkatan. Hasil tes kemampuan pemecahan masalah matematik pada tes awal hanya memiliki rata - rata kelas 65, 22. Pada siklus I, hasil tes meningkat cukup signifikan menjadi 71, 81. Pada siklus II mengalami perbaikan lagi dan rata-rata kelas untuk nilai tes kemampuan pemecahan masalah matematik siswa mencapai 83, 08 .

\section{DAFTAR PUSTAKA}

Jacobsen, D. A., Eggen, Paul, \& Kauchak, Donald. (2009). Methods for teaching (metode-metode pengajaran): Meningkatkan belajar siswa tk-sma. (Terjemahan Achmad Fawaid \& Khoirul Anam). New Jersey: Pearson Education, Inc. (Buku asli diterbitkan tahun 2009)

Hafitria, S. (2015). Meningkatkan Kemampuan Pemecahan Masalah Dan Berpikir Kreatif Matematis Siswa SMP dengan Menggunakan Pendekatan Pembelajaran Creative Problem Solving. Tesis. Jurusan Pendidikan Matematika UPI. Bandung: Tidak diterbitkan.

Hamiyah, N. dan Jauhar, M. (2014). Strategi Belajar-Mengajar Di Kelas. Jakarta: Prestasi Pustakaraya

Mariyam (2011). Model Pembelajaran Matematika Creative Problem Solving untuk Meningkatkan Hasil Pembelajaran Siswa Kelas VI SDN Ujung Berung 3 pada Pokok Bahasan Volum Bangun Ruang. Skripsi. Jurusan Pendidikan Matematika STKIP Siliwangi. Bandung: Tidak diterbitkan.

Pratiwi, R. (2013). Kajian Literatur tentang Heuristik dalam Pemecahan Masalah Matematika. Prosiding Program Studi Pendidikan Matematika SPs UPI.

Sari, R. M. M. (2013). Pengaruh Pendekatan Creative Problem Solving (CPS), Problem Solving (PS), dan Direct Instruction (DI), terhadap 
Peningkatan Kemampuan Berpikir

Kritis Matematis Siswa SMP.

TesisJurusan Pendidikan Matematika

UPI. Bandung: Tidak diterbitkan.

Sroyer, A. (2013). Pentingnya Quantitative

Reasoning (QR) Dalam Problem

Solving. Prosiding Program Studi

Pendidikan Matematika PMIPA FKIP

Universitas Negeri Yogyakarta.

Suhendar, A. (2014). Penerapan Model

Pembelajaran Creative Problem

Solving Untuk Meningkatkan Hasil

Belajar Siswapada Aplikasi

Pengolahan Angka. Skripsi. Jurusan

Pendidikan Ilmu Komputer UPI.

Bandung: Tidak diterbitkan.

Van de Walle, J. A. (2008). Matematika sekolah dasar dan menengah (6th ed.). (Terjemahan Suyono). Jakarta:

Penerbit Erlangga. (Buku asli diterbitkan tahun 2007). 